\title{
Pandemics and Populations
}

\author{
Jan Greguš* \\ Center of Outpatient Gynecology, Masaryk University, Czech Republic
}

Submission: December 21, 2020; Published: December 23, 2020

*Corresponding author: Jan Greguš, Center of Outpatient Gynecology, Masaryk University, Czech Republic

\section{Opinion}

2020 was the year of the COVID-19 pandemic, which overshadowed all other global challenges we face. Two of the most important are climate change - with its manifold consequences for the environment and health care - and human overpopulation, the main driver of climate change and other existential threats, alongside overconsumption [1-3]. As a gynecologist and reproductive rights advocate, I frequently write about overpopulation as a challenge all reproductive health providers need to take on as their responsibility - the connection between overpopulation and the pandemic is much closer than we think.

Despite the fact that the COVID-19 pandemic has caused the deaths of almost 1.7 million people to date [4] and caused longterm complications for many times that number, it may be viewed, from a long-term perspective, as the wakeup call we desperately needed. There are a few reasons for this.

The pandemic response showed how fundamentally unprepared, in general, we were to face the global spread despite our technological advancement, and furthermore, how undisciplined and even disobedient we were as citizens not to deliberately follow the guidelines recommended by authorities and experts. In other words, the pandemic revealed that we value our individual freedoms to the extent that we are not willing to make personal sacrifices for the common good. It has showed us that we lack persistance in enduring the hardships of social distancing over a longer period of time. It has showed us that, in pursuit of perpetual economic growth and financial profit, we are willing to risk our lives and health, and those of other people, such as our employees. The most disturbing thing that the COVID-19 pandemic showed us is how experts from various health-care fields have felt obligated to speak publicly about COVID-19 even though this topic was outside their specialization. They have frequently ignored, undermined, and sometimes even denied the threat of COVID-19, thus contributing to the immense public confusion that has worsened the effects of the pandemic.
Nevertheless, this difficult time in the history of the world has helped us uncover negative phenomena about ourselves and our society so that when another pandemic appears, perhaps more lethal than the previous one, we can be better prepared. It's necessary to state that new disease outbreaks of pandemic scale are a near mathematical certainty [5]. Their origins can be traced back to human overpopulation, which - in tandem with the overexploitation of nature - facilitates the emergence and spread of infectious diseases like COVID-19. So, though the current crisis took focus away from human overpopulation, it will implicitly return us to this problem because pandemics and populations are directly linked.

Though not specifically mentioned in the 2017 Scientists' Warning to Humanity, which stated in no uncertain terms that human beings are jeopardizing our collective future [2], there can be no doubt that the COVID-19 pandemic had its roots in environmental disruption and overpopulation [6]. Most current commentators have not made the connection yet; it is not even on their radar. Yet it is hardly unexpected that zoonotic disease viruses, being obligate intracellular parasites, would now and repeatedly utilise the vast "culture medium" presented by human flesh: our huge collective biomass [7]. Pandemics are, in truth, another symptom of the existential threat to all life resulting from an excess of human life $[8,9]$.

Zoonotic diseases are on the rise due to the destruction of wild habitats, vast and relentless deforestation, and the increasing consumption of meat products. Recent pandemics, such as Severe Acute Respiratory Syndrome (SARS) and Middle East Respiratory Syndrome (MERS), were zoonotic diseases - and while the origin of COVID-19 remains uncertain, studies have linked it to bats. The consumption of meat products, driven by a growing number of human consumers, is projected to double by mid-century [10], which will heighten the risk of new pandemics. 
In addition, the triple threat of human encroachment into natural habitats, urbanization, and globalization increases exposure to new viruses. A growing population means people must expand into areas where they might come into contact with an infected species. Urbanization, the movement of people from rural areas into cities, increases urban population density, and large human populations in cities and megacities represent ideal conditions for disease spread. Globalization results in close contact between populations, and their greater and faster movement within and between countries means diseases can spread more rapidly and extensively, as we witnessed this year. It is clear that population growth and environmental destruction fuel these deadly diseases [11].

However, this year gives us a rare chance of opportunity. More people than ever now understand the threat of exponential growth, both in the cases of the COVID-19 pandemic and the human "pandemic" (or ongoing rapid human population growth, however one calls it). Similarities of exponential growth between both pandemics can help people to realize the later we start acting, the more draconic measures we must put into play. Whereas in the initial phases, benign measures such as optional social distancing, wearing masks, and increased hygiene would have been enough [12], governments had to enforce strict measures like lock-downs in response to steadily increasing numbers, mainly due to the lack of civilian discipline and resistance against authorities and experts.

Whereas the COVID-19 pandemic was not within our field or our reach, the human pandemic clearly is. It is upon us, experts in the field of women's health, to take on this pandemic as our own challenge and intensify our efforts in providing women and couples worldwide the family planning methods necessary to prevent unintended pregnancies [13], and thus stop the pandemic of human births which ravages a planet that is currently struggling to support them. Furthermore, to curb and ultimately reverse population growth through ethical, choice-based solutions, we must promote the reproductive ethics of fewer-child families (a maximum of two children, i.e. replacement level, and ideally less) [13], until we reach sustainable population numbers. Just as epidemiologists have asked humans to wear masks or stay home, we gynecologists must now ask humans - compassionately and humanely - to have small families. The sooner we start actively advocating for this, the larger the chance that no metaphorical "lock-downs," such as a universal one-child policy, will ever need to be enforced in order to bring human populations down to sustainable levels.
It may seem absurd just after so many people have died from the novel coronavirus to call for a decrease in natality, but it is necessary to look towards the bigger picture and acknowledge the undisputed fact that without a sustainable population, there cannot be a sustainable environment for human life. If anything, COVID-19 has given us the chance to double down on an urgent need for sustainability and harmony between humanity and nature. If we act now, the disruption caused by COVID-19 countermeasures and associated reductions in economic activity may, long-term, save many more lives than have been lost to the outbreak. One can only hope that the viral pandemic will further an appreciation of the clear danger of human pandemic, a phantom menace that has - sadly - still too little recognition amongst the public, governments and the media.

With the world combating an acute health crisis on a scale unprecendented in recent years, urgent actions are essential. If we want to stop and prevent other pandemics to come, we and the policy-makers must address the drivers and risks of pandemic diseases, i.e. human populations.

\section{References}

1. Kendall H (1992) World Scientists' Warning to Humanity.

2. Ripple WJ (2017) World Scientists' Warning to Humanity: A Second Notice. Bioscience 67(12): 1026-1028.

3. Ripple WJ (2019) World Scientists` Warning of a Climate Emergency. Bioscience 70(1): 8-12.

4. World Health Organization (2020) WHO Coronavirus Disease (COVID-19) Dashboard.

5. Qui J (2020) How China's 'Bat Woman' Hunted Down Viruses from SARS to the New Coronavirus. Scientific American.

6. Quammen D (2020) Shaking the Viral Tree. Emergence Magazine.

7. Yinon M (2018) The Biomass Distribution on Earth. PNAS 115(25): 6506-6511.

8. Quamen D (2012) Spillover: Animal Infections and the Next Human Pandemic. Kindle Edition.

9. United Nations Environment Programme (UNEP). UNEP Frontiers 2016 Report. Emerging Issues of Environmental Concern.

10. (2019) Food and Agriculture Organization of the United Nations (FAO). Meat \& Meat Products.

11. Nater 0 (2020) Population Growth and Environmental Destruction Fuel Deadly Diseases. Population Matters.

12. Centers for Disease Control and Prevention (2020) How to Protect Yourself \& Others.

13. Greguš J, Guillebaud J (2020) Doctors and Overpopulation 48 Years Later: A Second Notice. The European Journal of Contraception and \& Reproductive Health Care 25(6): 409-416. 


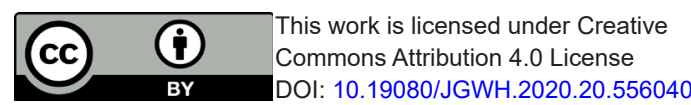
Commons Attribution 4.0 License DOI: 10.19080/JGWH.2020.20.556040

\section{Your next submission with Juniper Publishers} will reach you the below assets

- Quality Editorial service

- Swift Peer Review

- Reprints availability

- E-prints Service

- Manuscript Podcast for convenient understanding

- Global attainment for your research

- Manuscript accessibility in different formats ( Pdf, E-pub, Full Tsext, Audio)

- Unceasing customer service

Track the below URL for one-step submission https://juniperpublishers.com/online-submission.php 